\title{
Valuing Florida Water Resources: Prices of Waterfront Properties ${ }^{1}$
}

\author{
Tatiana Borisova, Xiang Bi, Tara Wade, Kurt Oehlbeck, and Kelly Grogan²
}

\section{Introduction}

This fact sheet is a part of a series, "Economic Value of Florida Water Resources." While other publications in the series discuss tourism and recreation, water supply, and other ecosystem services provided by water resources, this one explores the relationship between water quality and sale prices of waterfront properties, that is, the amenity value provided by water resources to waterfront communities. Proximity to water generally increases the value of a residential property. However, poor water quality may decrease waterfront property prices. In other words, investments in restoring water quality can translate into increases in property value and tax collection.

Sale prices for residential properties reflect customers' willingness to pay for various structural, locational, and neighborhood property characteristics, such as the number of bedrooms and bathrooms, the size of the lot, the age of the house, proximity to the city center, etc. One of the locational characteristics that buyers are willing to pay for is the proximity to water resources (waterfront properties generally cost more), and this willingness to pay may depend on the condition of the water resource. The analysis of property sale prices to determine willingness to pay for various property attributes is the "hedonic property price analysis method." Note that the economic studies focus on the actual sale prices of the properties, as opposed to the just values assigned by the property appraisers, which may depend on the appraisers' methodology. Sale prices reveal buyers' true willingness to pay.

This publication focuses on the studies conducted in Florida since 2000 that focused specifically on the potential effect of water quality on property values. The studies were identified through Google Scholar searches. The studies found and reviewed in this paper focus on four urban regions: the Jacksonville area (properties along the St. Johns River and its tributaries in Duval county), the Orlando area (properties around lakes in Orange County), and coastal Martin County and Lee County (properties along the Caloosahatchee River, the St. Lucie Estuary and River, the Loxahatchee Estuary, and the Indian River Lagoon).

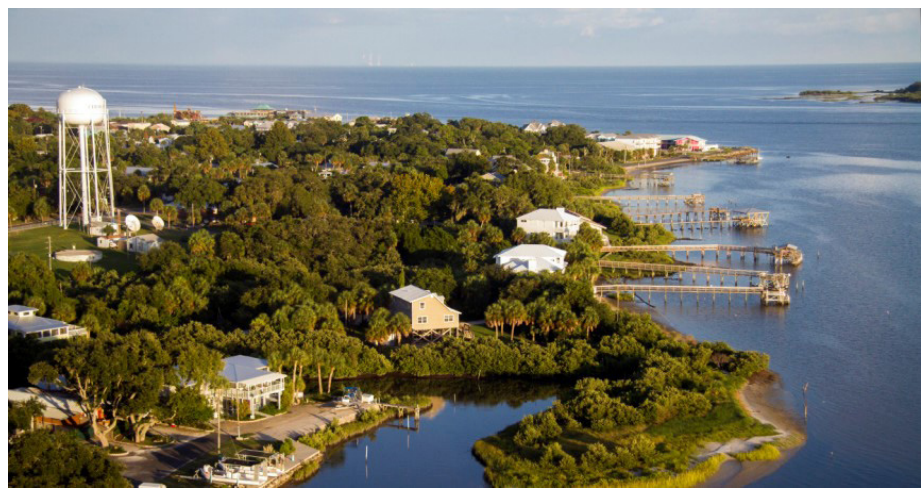

Figure 1. Example of coastal waterfront properties Credits: PIE Center, UF/IFAS, http://www.piecenter.com/2016/02/12/ survey-floridians-tap-water-as-major-concern/

1. This document is FE1062, one of a series of the Food and Resource Economics Department, UF/IFAS Extension. Original publication date July 2019. Visit the EDIS website at https://edis.ifas.ufl.edu for the currently supported version of this publication.

2. Tatiana Borisova, assistant professor and Extension specialist, Food and Resource Economics Department; Xiang Bi, assistant professor, Food and Resource Economics Department; Tara Wade, assistant professor, Food and Resource Economics Department, UF/IFAS Southwest Florida Research and Education Center; Kurt Oehlbeck, former undergraduate student, Food and Resource Economics Department; and Kelly Grogan, associate professor, Food and Resource Economics Department; UF/IFAS Extension, Gainesville, FL 32611.

The Institute of Food and Agricultural Sciences (IFAS) is an Equal Opportunity Institution authorized to provide research, educational information and other services

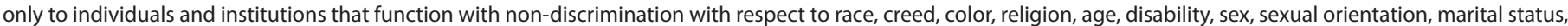

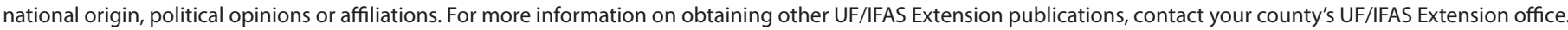
U.S. Department of Agriculture, UF/IFAS Extension Service, University of Florida, IFAS, Florida A \& M University Cooperative Extension Program, and Boards of County Commissioners Cooperating. Nick T. Place, dean for UF/IFAS Extension. 
Note that buyers' willingness to pay for property characteristics is highly pliable and context-dependent. Willingness to pay can depend on the buyer's tastes, emotional state, income level, and other characteristics. The economic cycle also impacts property prices and customers' willingness to pay for various property characteristics. Furthermore, monitoring data are available for a few water-quality parameters only, and the conclusions from the economic studies can vary depending on the water-quality indicators considered.

\section{Indicators Used to Evaluate Water Quality in Hedonic Price Analysis Studies}

Economic studies rely on existing water-quality monitoring data that are collected as a part of various government or community programs. The monitoring programs were set up to evaluate subtle changes in physical, chemical, or biological characteristics of the water resources, and economists face the challenge of selecting indicators that best reflect buyers' perceptions of water quality.

Nutrient (nitrogen and phosphorus) water pollution is one of the most widespread water quality issues nationwide (EPA n.d. a.) and in Florida (FDEP 2019). Nutrient water pollution can be linked to fertilizer use on residential and agricultural lands, leaky septic tanks, wastewater treatment plant discharges, and other sources. Nitrogen and phosphorus loading can cause excessive algae grow, and since algae breath and consume oxygen, their overabundance decreases the amount of dissolved oxygen available in water for fish and other aquatic organisms. The events when algal growth is especially large are referred to as "algal blooms" and they can lead to the death of fish and other aquatic organisms. Some algal blooms produce toxins that can be harmful to humans who come in contact with water or consume affected fish or shellfish (EPA n.d. a).

Given the importance of assessing costs and benefits of nutrient water pollution reduction, many studies focus on examining the effect on waterfront properties of nutrientrelated water-quality changes. Several studies employ Secchi Disk Measurement (SDM), an indicator of water transparency for which the measurements are widely available (though they may not be as rigorous in indicating the state of the water resources as other parameters monitored through government programs). SDM measurements are taken by lowering the Secchi disk into the water to a depth at which the observer can no longer see the disk (Figure 2). SDM can help identify nutrient pollution because nutrient load can lead to blooms of microalgae that increase water turbidity.

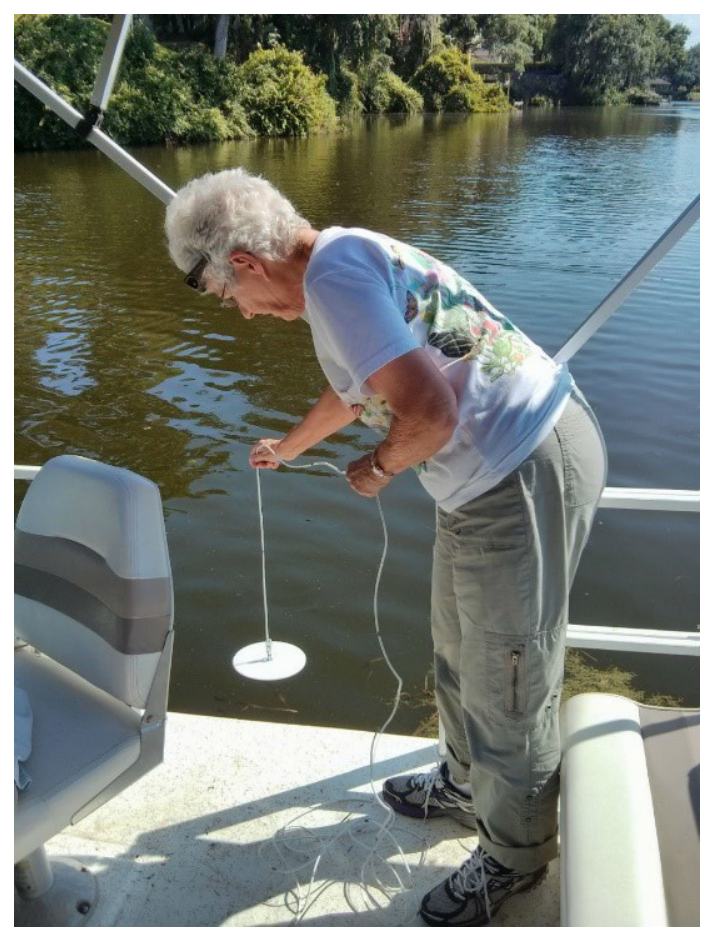

Figure 2. A Lakewatch volunteer in Lakeland, FL, demonstrates how to take a Secchi disk sample.

Credits: Shannon Carnevale, UF/IFAS (http://blogs.ifas.ufl.edu/ polkco/2017/10/12/lakewatch-polk-county-volunteer-water-programneeds-help/)

The abundance of microalgae and reduction of water clarity can also be evaluated through chlorophyll concentration measurements. Chlorophyll is unique to plants (it is important for plants' production of organic compounds), and therefore measuring chlorophyll concentration in water helps identify the presence of algae (EPA n.d.b.). In turn, dissolved oxygen (DO) is important for survival of fish and other aquatic life, and reduction in DO can be a sign that the water ecosystem is misbalanced (EPA n.d. b.). Other water-quality indicators include water temperature (which influences the rates of chemical and biological reactions in water), $\mathrm{pH}$ (which measures water acidity or alkalinity), and salinity (which determines which plants and animals can survive in water).

Given the diversity of indicators, some economic studies rely on aggregate indicators to account for various aspects of physical, chemical, and biological conditions of water resources. For example, the trophic state index (TSI) is calculated using total nitrogen concentrations, total phosphorus concentrations, total chlorophyll concentrations, and SDM. The index ranges from 1 to 100. Higher values (above 70 ) can be associated with an abundance of algae, and such water resources are often classified as 
not supporting recreational activities (even though they may still be associated with an abundance of fish and thus otherwise conducive to fishing) (Florida Lakewatch 2017). Some economic studies considered using news reports related to water pollution issues as a sign of public concerns about water quality. For example, news related to harmful algal blooms usually attracts significant public attention, partially because such blooms can produce toxins harmful to people. To learn more about harmful algal blooms, consult the UF/IFAS publications listed here: https://edis. ifas.ufl.edu/topic_harmful_algal_blooms). (UF/IFAS EDIS n.d.)

\section{Proximity to Water as an Important Attribute of Residential Properties: Two Studies from \\ Duval County}

Proximity to water resources is an important characteristic influencing many buyers in their purchase decisions. That proximity can be an amenity (e.g., buyers may anticipate enjoying recreational opportunities or aesthetic pleasure from a "water view") or a disamenity (e.g., buyers may consider the probability of flooding that increases for properties near water) (Cohen et al. 2015).

Two Florida-based studies reported on the effect of proximity to water on residential property values, and both studies focused on single-family residential property sale prices in Duval County from 2003 to 2015. A summary of Seidel, Milon, Barker, and Diamond's 2015 study titled Economic Impact of the St. Johns Water Quality on Property Values was submitted as a report to the Saint Johns River Water Management District (one of five regional water districts in Florida) (Seidel et al. 2015). This study considered home sales near the St. Johns River and its tributaries, for houses located within 4921 feet (or 1500 meters) from the edges of the St. Johns River or its tributaries. Most of the properties were sold in Duval County, with just a few sales in Clay, Putnam, and St. Johns Counties. A statistical model was estimated with the sale price as a dependent variable, and home, community, and household characteristics, as well as other variables as independent variables assumed to explain the variation in the sale prices. The analysis showed that the waterfront amenity added significantly to the sale price, that is 46.2 percent of the sale price for the riverfront locations, and 45.3 percent of the sale price for the tributary-front location. The study indicated that of the total $\$ 5.2$ billion in property sales examined, approximately $\$ 650$ million in sales value was for the waterfront homes, and for the properties sold during the time period studied, $\$ 300$ million in value was attributable solely to river and tributary frontage, all else being equal. For every additional 33 feet (10 meters) of distance from the river, the study showed a reduction in property value of approximately $\$ 300$ (all else being equal).

Seidel et al. (2015) did not account for the effects of the economic cycle on the housing market and home sale prices. Meanwhile, the time period they considered, 2003-2015, covered the rise and fall of the housing market that potentially influenced buyers' willingness to pay for various property attributes, including waterfront location. To account for the effect of the economic cycle, Hilliard (2015) developed an alternative statistical model in her M.S. thesis completed at the University of Central Florida. Hilliard's model enabled her to estimate the relationship between property sale prices and various property attributes (such as square footage of living area, property land acreage, age of the house), property location (e.g., proximity to the St. Johns River or its tributaries, or to the central business district), community (e.g., racial composition of the neighborhood), and household characteristics (e.g., mean income of householders in the area). Like the statistical analysis in the study by Seidel et al., Hilliard's statistical analysis showed that for otherwise comparable properties, the greater the distance from the property to the river, the lower the sale price. Hilliard's study also showed that waterfront property prices did not decline during the recent recession, maintaining the price premium (either due to smaller numbers of waterfront houses sold or in recognition that proximity to the waterfront is a special amenity even during a market downturn). The study estimated that for the properties on the riverfront of the St. Johns River, 64 percent of the property prices was an implicit value for the waterfront. For the waterfront properties along the tributaries, 55 percent of sales prices was the implicit value for the waterfront. The study further explains it as follows:

Using the average riverfront property sales prices of $\$ 791,559$, the implicit price for the riverfront feature in the residential property was $\$ 506,598$. Similarly, the implicit price for the water amenity for tributary front residential properties was $\$ 333,740$ (...)(p. 36).

On average, the sale price declined by $\$ 175.5$ for every 33 feet (or 10 meters) of distance from a riverfront. This average effect was even larger during recession (\$348.7) (Figure 3). Overall, Hilliard's study highlights that proximity to the river is an amenity valued by the buyers during both boom and bust periods of the housing market. 


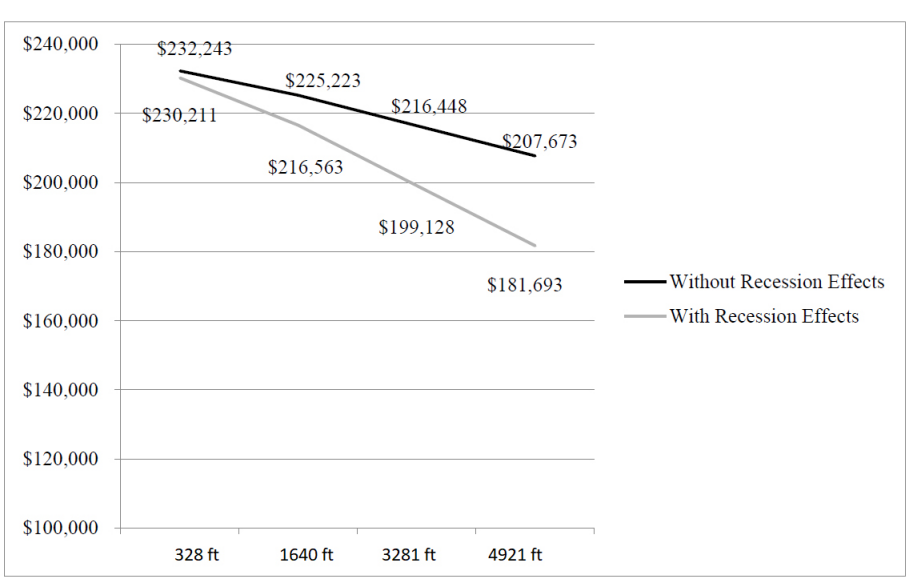

Figure 3. Average sale price of a house displaying implicit prices for distance to riverfront with and without accounting for recession effects.

Credits: Based on Hilliard (2015)

\section{Water Quality and the Prices of Waterfront Properties}

In addition to the proximity effect, several studies examined the effect of water quality on the sale prices of waterfront properties. Conclusions from the studies diverge, likely due to the use of dissimilar water quality indicators to capture water quality and its perception by home buyers.

\section{Water Quality of the Lower St Johns River and Its Tributaries}

As discussed above, two studies examined the effect of the proximity to the St. Johns River and its tributaries on single family residential property sale prices: a report to a water management district (Seidel et al. 2015) and an M.S. thesis completed at the University of Central Florida (Hilliard 2015). Both studies focused on single family residential property sales from 2003-2015 and considered properties within 4921 feet (or 1500 meters) from the rivers' edges. The studies differed in the treatment of boom and bust cycles in the housing market, with Hilliard (2015) explicitly accounting for fluctuations in the market, unlike Seide, et al. (2015), as well as in the treatment of home sales in Clay, Putnam, and St. Johns Counties, with Hilliard (2015) excluding them and Seide, et al. (2015) including them. In addition, the studies considered different indicators of water quality.

As a measure of water quality, Hilliard (2015) used quarterly averages of chlorophyll for different monitoring stations along St. Johns River and its tributaries. Despite the fact that being on the waterfront was of significant value, the study found no statistically significant correlation between the property sale prices and chlorophyll concentrations. This result may reflect the fact that some water quality indicators, although capturing the state of water resources, may not accurately reflect buyers' perceptions of water quality.

Seidel et al. (2015) measured the "health" of the river and its tributaries using SDM (annual average values for 15 out of 16 St. Johns River stretches considered in Duval, Clay, Putnam, and St. Johns Counties). In separate econometric models, their study considered the trophic state index and reports related to the harmful algal blooms along the relevant stretches of the river. The study found no statistically significant correlation between sale prices and reported harmful algal blooms or sale prices and the trophic state index. The SDM measure, however, was found to significantly correlate with property sale prices. Even though the waterfront properties enjoyed higher prices compared with the homes not facing the river, this difference in price depended on the clarity of the river water. For the property sales considered, the relevant SDM measurements ranged from approximately 6 feet ( 1.8 meters) to less than 2 feet $(<0.5$ meter $)$. The study reports that:

...for riverfront properties with Secchi Disk measures greater than 1.5 (1.86 was the maximum in the dataset), up to $24 \%$ of the premium associated with river frontage could be attributable to the clearer water conditions. For riverfront properties that sold at times when the water was not as clear by Secchi disk measures, as in the 32 sales at $0.5 \mathrm{~m}$ or 748 sales at less than 1.0 meter, the premium drops to 6-9\% (Siedel et al., p. 197).

The authors estimated that if all riverfront properties were adjacent to the highest water quality (i.e. five feet clarity, measured with SDM), the hypothetical increase in the economic value attributable to the water quality improvement in the study area would be $\$ 346.1$ million, and the property tax revenue associated with this increase in water quality would total $\$ 45.3$ million over 20 years. This estimated value could be used to illustrate the importance of investments in protecting and restoring St. Johns River water quality.

\section{Water Quality in Coastal Areas: Martin and Lee Counties}

Three studies examined the link between single family home sale prices and water quality in coastal areas in Martin and Lee Counties. One study, a report developed by FloridaRealtors (the trade association of Florida realtors), considered a four-year period, from 2010 to 2013 (FloridaRealtors 2015). Similar to the studies above, the report developed a statistical model in which home sale prices 
were analyzed as a function of home structural characteristics (the age and size of the house), locational characteristics (school quality scores, percent of residents less than age 18, waterfront homes, distance to the ocean and other major waterbodies), as well as monthly and annual average measurements of water quality characteristics. The study primarily used SDM, though the researchers did consider other measures of water quality when data were available. Each of the home sales was assigned to the closest water quality monitoring station on Caloosahatchee River and St. Lucie River coastal areas. The study examined the effect of water quality based on the average of measurements taken for the month before the sale. In a separate model, researchers averaged the water quality measurements taken during the year before the house was sold.

In the FloridaRealtors study, water quality was found to correlate with property sale price, and the correlation was stronger for the annual average water-quality measurement (possibly due to the fact that home buyers react more strongly to long-term changes in water quality). SDM measurements had a larger estimated effect on property prices as compared with the other indicators. The estimated effect of water quality on property sale prices declined significantly with distance from waterfront. For Caloosahatchee River Estuary (Lee County), an increase in water transparency by 1 foot (measured through annual mean value of SDM prior to sale) resulted in a $14.7 \%$ increase in average waterfront property prices (other things being equal). This effect was smaller with increased distance from the waterfront; however, the report concluded that even for properties one mile from Caloosahatchee River Estuary, an increase in the water transparency resulted in a $2.0 \%$ increase in property sale price. Similar results were found for Martin County. For St. Lucie Estuary, Loxahatchee Estuary, and Indian River Lagoon north of St. Lucy Inlet, an increase in water transparency by 1 foot (measured through annual mean value of SDM) was estimated to increase average waterfront property prices by 10.3 percent. Even at a distance of 1 mile from the waterfront, the effect of such an increase in the water transparency on the property prices was statistically significant and estimated to average 1.4 percent.

The FloridaRealtors study concluded that there were significant economic implications from improved average water clarity. Lee County's aggregate property values could potentially increase by an estimated $\$ 541$ million in response to a one-foot increase in average Secchi disk depth throughout the Caloosahatchee Estuary (if Just Value of the properties were used as a measure of their sale prices).
In turn, Martin County's aggregate property values could increase by an estimated $\$ 428$ million in the scenario of a one-foot increase in average SDM throughout the St. Lucie Estuary, Loxahatchee Estuary, and the portion of the Indian River Lagoon north of the St. Lucie Inlet. These increased property values would also provide additional tax revenue for city and county governments (FloridaRealtors 2015).

Two other studies also examined the effect of water quality improvements on the waterfront property prices in coastal areas of Martin County, FL, along St. Lucie River, St. Lucie Estuary, and Indian River Lagoon (Bin and Czajkowski 2013; Bin et al. 2017). Unlike the studies discussed above, both studies were published in peer-reviewed journals, and therefore their estimated methodology was vetted by peer economists. Bin and Czajkowski (2013) used waterfront home sales from 2000-2004 and a variety of indicators of water quality: temperature, $\mathrm{pH}$, water clarity, salinity, and dissolved oxygen. The study also considered a water quality grade, which was an aggregate of the water quality parameters mentioned above, excluding temperature. The grade ranged from A to F; it was developed by the Florida Oceanic Society with the goal to give the public an easy way to evaluate river water quality. Six monitoring stations with weekly water quality measurements were considered, and median values of weekly measures of all the water quality indicators taken over the year of the sale were used.

With mean sale prices in the sample of $\$ 937,295$ per home and average water clarity, the authors found that increasing average water clarity by one percent (measured as Secci depth divided by water depth) resulted in a $\$ 36,070$ increase in property sale price, on average. In other words, increasing average water clarity by one percent resulted in a $3.8 \%$ increase in waterfront property prices, other things being equal. Bin and Czajkowski also found that changes in salinity, $\mathrm{pH}$, and dissolved oxygen, as well as the aggregate water quality grade, had a statistically significant effect on waterfront property prices. For the aggregate water quality grade, the study found that a one percent increase in water quality grade is valued at $\$ 43,158$ by property buyers, on average (or $\$ 43,158 / \$ 937,295=4.6 \%$ ) (Bin and Czajkowski 2013).

In turn, Bin et al. (2016) considered the coastal areas of Martin County, FL, along the St. Lucie River, the St. Lucie Estuary, and the Indian River Lagoon, and focused on the weekly measures of the aggregate water quality grade (a composite indicator of the $\mathrm{pH}$, salinity, clarity, and dissolved oxygen, similar to "grade" mentioned in the Bin and Czajkowski study). The 2016 study considered a longer period of home sale observations-from 2001 to 2010. 
This study found a smaller but still statistically significant effect of water quality changes on the property prices: a one percent increase in water quality grade was valued at $\$ 2,614$ by the property buyers, on average. Given that the average property price in the sample was $\$ 810,111$, this can be translated into $0.3 \%$ increase in the property price for a one percent increase in the aggregate water quality grade. While this estimate is significantly smaller than the estimate found in the other studies, it is important to note that the period of observation, from 2001 to 2010, covered the boom and bust of the housing market. The study showed that even during periods of economic downturn, waterfront property buyers were willing to pay a price premium for water quality. It also confirmed that there may be significant economic returns associated with water quality protection during these periods.

\section{Lake Water Quality: Orange County}

The value of changes in lakes' water quality for home owners was examined in urban Orange County by several studies (Walsh 2009, Walsh et al. 2010, Walsh and Milon 2016). The studies developed several statistical models to assess the effect of water quality on single family residential property prices. The studies relied on various indicators of water quality, which resulted in a range of estimated benefits. The most recent study, Walsh and Milon (2016), explored the implications of using various water quality indicators. This study was published in a peer-reviewed journal and we deemed it the most comprehensive of the three lake water quality studies.

Along with the homes' proximity to natural lakes and the lakes' water quality, Walsh and Milon's study accounted for other home locational characteristics (such as proximity to the central business district-downtown Orlando-and distance from the airport noise zone), home structural characteristics (such as age and size), socio-demographic characteristics of the communities (such as median household income, education level, percent of adults older than 65 years old, and the percent of minorities), and the lakes' natural background conditions (measured by lakes' alkalinity, i.e., the ability of a lake to neutralize acids)

(Walsh and Milon 2016). Walsh and Milon examined sales of single-family residential properties located within 3,281 feet (or 1 kilometer) of one of 76 lakes for the 1996-2004 period. The average home sale price was $\$ 230,000$ (adjusted for inflation to 2002 prices). Walsh and Milon examined several econometric models, with the water quality in the lakes linked to total nitrogen, total phosphorus, chlorophyll, or the trophic state index using the annual mean value of the indicators for the year before the sale.
In this study, the benefits of improving water quality varied dramatically depending on the water quality indicator used. For example, for properties within 3,281 feet of Lake Copeland, the benefits of reducing total nitrogen concentration to meet Florida's surface water quality standards were $\$ 860,000$ when measured with the econometric model with total nitrogen concentration as an independent variable. However, when water quality improvements to meet water quality standards were translated into changes in the trophic state index, the estimated benefit of the improvement was more than 100 times smaller (only $\$ 8,500$ ). Similarly, for properties within 3,281 feet of Lake Olive, the benefits of improving the lake's water quality to Florida's total phosphorus water quality criterion were $\$ 22,021$. However, when the improvements were translated into changes in the trophic state index, the estimated benefits were only approximately $\$ 5,000$. Such drastic differences in estimated values of various water quality improvements were due to the fact that the changes in total nitrogen or total phosphorus required by the state criteria may not be needed to improve the ecology of the lakes to a "healthy" state (depending on whether a particular nutrient targeted by the state criteria is a limiting factor for the growth of aquatic organisms). In other words, significant changes in nitrogen and phosphorus concentrations may not lead to big changes in the tropic state index if the nutrients are not as critical for the state of aquatic ecosystems.

Walsh and Milon's study further elaborated that a composite indicator such as the trophic state index is more reflective of the ecological state of the lakes and therefore a better predictor of likely public perceptions of water quality, which ultimately influences the property sale price. The study concluded that such a composite index was a better indicator of water quality impacts on property values.

Table 1 below reports the estimated benefits of simultaneously decreasing the concentration of nutrients (total nitrogen and total phosphorus) and chlorophyll to meet Florida's water quality criteria, and then using the trophic state index to relate the water quality improvements to the property sale prices. While the estimated effects of water quality improvements on property sale prices are modest, they nevertheless show that improving water quality has a value for homeowners. The results also imply that improvement of water quality to meet Florida's standards may not always translate to perceived improvement of water quality. For example, in Table 1, for Lake Pineloch, the trophic state index does not change in response to changes in nutrients and chlorophyll, and, therefore, no changes in property sale 
prices can be expected in response to meeting water quality standards.

The benefits estimated in the Walsh and Milon study (2016) are the most conservative among the three studies focused on lakewater quality in Orange County (Walsh 2009, Walsh et al. 2010, Walsh and Milon 2016). Walsh et al. (2010) estimated that an increase in Secchi depth by one foot (an increase in water clarity) resulted in an increase in average home sale price of about $1.2 \%$ (or $\$ 6,900$ ) for lakefront properties, and $0.3 \%$ (\$880) for non-lakefront properties within 3,281 feet of the lake. Given the large number of lakes in Orange County and the significant number of houses surrounding them, this estimate implies that changes in water quality can translate into significant changes in state taxes paid from home sales associated with changes in the quality of water. The difference among the studies shows the significant effect that the choice of water quality indicator can have on the estimated importance of water quality for property sale prices. Walsh and Milon's 2016 study is the most recent and was published in a peer-reviewed journal.

\section{Conclusion}

The studies reviewed in this article were conducted in different geographic locations; they used different measures of water quality; and they examined home sale prices over different time periods. They all conclude that proximity to a river, lake, or coast is valued by homeowners, with increased prices for waterfront properties. Two of the studies considered the effect of the economic downturn of 2008-2010 on housing prices and concluded that even during a downturn, buyers valued proximity to a water resource.

The results of the various studies regarding the effect of water quality changes on property prices were diverse, with various indicators used to characterize water quality. Overall, the studies gave examples of measurable and significant effects of water quality on property prices, illustrating the importance of investing in water resource protection and restoration. The differences in the estimation results also emphasize the importance of comparing the modeling results using various water quality indicators to find the indicator or combination of indicators that is most consistent with homeowners' perception of water quality and that correlates most closely to their willingness to pay for water quality.

\section{References}

Bin, O. and J. Czajkowski. 2013. "The Impact of Technical and Non-technical Measures of Water Quality on Coastal Waterfront Property Values in South Florida." Marine Resource Economics. 28(1): 43-63.

Bin, O., J. Czajkowski, J. Li, and G. Villarini. 2017. "Housing Market Fluctuations and the Implicit Price of Water Quality: Empirical Evidence from a South Florida Housing Market." Environmental \& Resource Economics. 68(2) 319-341.

Center for Disease Control and Prevention (CDC). 2017. Harmful Algal Bloom (HAB)-Associated Illness. https:// www.cdc.gov/habs/index.html

Cohen, J. P., R. G. Cromley, and K. T. Banach. 2014. "Are homes near water bodies and wetlands worth more or less? An analysis of housing prices in one Connecticut town." Growth and Change 46(1) 114-132.

FDEP (Florida Department of Environmental Protection). 2019. Integrated Water Quality Assessment for Florida. https://floridadep.gov/dear/dear/content/ integrated-water-quality-assessment-florida

Florida Lakewatch. 2017. A Beginner's Guide to Water Management - The ABCs. Description of Commonly Used Terms. Information Circular 101. University of Florida, IFAS. http://edis.ifas.ufl.edu/pdffiles/FA/FA07800.pdf

FloridaRealtors. 2015. The Impact of Water Quality on Florida's Home Values. https://www.floridarealtors.org/ ResearchAndStatistics/Other-Research-Reports/upload/ FR_WaterQuality_Final_Mar2015.pdf

Hillard, A. L. 2015. "Effects of Real Estate Cycles on Residential Amenity Values for Water Resources." University of Central Florida. http://stars.library.ucf.edu/ honorstheses1990-2015/1866

Seidel, V., W. Milon, A. Barker, and C. Diamond. 2015. Economic Impact of the St. Johns Water Quality on Property Values. In: Hackner, C.T. (ed). St. Johns River Economic Study. Report submitted to the St. Johns River Water Management District under contract \#27884. https:// www.sjrwmd.com/static/waterways/St._Johns_River_Economic_Study.pdf 
UF/IFAS CAIP (University of Florida Institute of Food and Agricultural Sciences Center for Aquatic and Invasive Plants). n.d. Plant Management in Florida Waters - An Integrated Approach: Algae. UF / IFAS Center for Aquatic and Invasive Plants. https://plants.ifas.ufl.edu/manage/ why-manage-plants/aquatic-and-wetland-plants-in-florida/ algae/

UF/IFAS EDIS (University of Florida Institute of Food and Agricultural Sciences Electronic Data Information Source). n.d. Harmful Algal Blooms. https://edis.ifas.ufl.edu/ topic_harmful_algal_blooms

EPA (U.S. Environmental Protection Agency). n.d. a. Nutrient Pollution. https://www.epa.gov/nutrientpollution/issue

EPA (U.S. Environmental Protection Agency). n.d. b. Indicators Used in the National Aquatic Resource Surveys. https://www.epa.gov/national-aquatic-resource-surveys/ indicators-used-national-aquatic-resource-surveys

EPA (U.S. Environmental Protection Agency). n.d. c. State Progress Toward Developing Numeric Nutrient Water Quality Criteria for Nitrogen and Phosphorus. https:// www.epa.gov/nutrient-policy-data/state-progress-towarddeveloping-numeric-nutrient-water-quality-criteria

Walsh, P., W. Milon, and D. Scrogin. 2010. The spatial extent of water quality benefits in urban housing markets. Working Paper \#10-02. National Center for Environmental Economics, United States Environmental Protection Agency, Washington, D.C. http://yosemite.epa.gov/ee/epa/eed.nsf/4 4a8be610f6c5f0885256e46007b104e/b4676c54814e0680852 576da00601559/\$FILE/2010-02.pdf

Walsh, P. 2009. Hedonic property value modeling of water quality, lake proximity, and spatial dependence in Central Florida. PhD dissertation, Department of Economics, The University of Central Florida, Orlando, FL. http://etd.fcla. edu/CF/CFE0002717/Walsh_Patrick_J_200908_PhD.pdf.

Walsh, P., and W. Milon. 2016. Nutrient Standards, Water Quality Indicators, and Economic Benefits from Water Quality Regulations. Environ Resource Econ. 64:643-661. 
Table 1. Benefits of achieving all nutrient criteria for five lakes in Orange County, estimated as expected increase in sales price for properties within 3,281 feet of the lake (Welsh and Milon 2015).

\begin{tabular}{|c|c|c|c|}
\hline Lake & $\begin{array}{l}\text { Baseline trophic state } \\
\text { index }\end{array}$ & $\begin{array}{l}\text { Trophic state index after changes in nutrients } \\
\text { and chlorophyll to meet Florida's surface water } \\
\text { quality standards }\end{array}$ & Estimated benefits \\
\hline Lake Copeland & 62.37 & $57.71-59.27$ & $\$ 3,645$ \\
\hline Lake Mann & 46.68 & 46.09 & $\$ 275$ \\
\hline Lake Olive & 52.28 & 48.27 & $\$ 3,414$ \\
\hline Lake Pineloch & 54.09 & 54.09 & $\$ 0$ \\
\hline Lake Sybelia & 50.54 & $42.36-47.08$ & $\$ 68,827$ \\
\hline
\end{tabular}

